\title{
Peningkatan Mutu Dan Pendapatan Pengolah Ikan Cakalang Asap Di Desa Pontoh Kecamatan Wori Kabupaten Minahasa Utara Provinsi Sulawesi Utara
}

\author{
Engel Victor Pandey* dan Jenki Pongoh \\ Fakultas Perikanan dan Ilmu Kelautan, Universitas Sam Ratulangi. \\ Jl. Kampus Unsrat Bahu, Manado 95115, Sulawesi Utara, Indonesia. \\ *Penulis Korespondensi: engelpandey@yahoo.com \\ (Diterima 10-10-2019; Direvisi 18-10-2019; Dipublikasi 24-10-2019)
}

\begin{abstract}
A low level of sanitation and hygiene applied by smoked fish processors in North Sulawesi can affect the quality and safety of the product itself. Interestingly, there is a huge market demand of smoked fish product in North Sulawesi. That is why it is necessary to improve quality of smoked fish product by assisting the smoked fish processors. The program's target partners are located in Desa Pontoh, Kecamatan Wori, Kabupaten Minahasa Utara which is geographically located on the coast Desa Pontoh is categorized as a fishing community, which is about $50 \%$ classified as poor families and has a small business group of processing smoked fish. The aim of this program is to increase production, marketing and finance for small entrepreneurs in Desa Pontoh, Kecamatan Wori, Kabupaten Minahasa Utara so they can be skilled and economically independent. The specific target of this activity is to produce smoked fish products that are superior in terms of taste and shelf life while providing business continuity and strong management. The method of implementation that will be applied to this program are 1) Training on how to produced smoked-fish product using good manufacturing practices 2) Assisting about sanitation and hygiene in every step of producing smoked fish; 3 ) Advising on management.
\end{abstract}

Keywords: smoking, production, marketing, finance

\begin{abstract}
ABSTRAK
Pengolahan ikan asap di Sulawesi Utara umumnya masih dilakukan secara tradisional dengan tingkat sanitasi dan higienis yang rendah sehingga dapat mempengaruhi mutu, kualitas serta keamanan produk itu sendiri. Melihat potensi ikan asap sebagai produk lokal andalan Sulawesi Utara, maka perlu adanya upaya perbaikan kualitas agar semakin diminati dan konsumen tetap mendapatkan jaminan keamanan dalam mengkonsumsi produk tersebut. Selain itu untuk meningkatkan masa simpan produk ikan asap agar dapat memperpanjang rantai distribusi penjualan. Mitra sasaran program ini berlokasi di Desa Pontoh Kecamatan Wori Kabupaten Minahasa Utara yang secara geografis terletak di pesisir pantai dengan potensi perikanan laut yang potensial untuk dikembangkan. Desa Pontoh dikategorikan sebagai masyarakat nelayan, yang sekitar 50\% tergolong keluarga miskin dan mempunyai kelompok usaha kecil pengolah ikan asap yang merupakan salah satu produk olahan yang digemari oleh masyarakat sekitar dan pemasaran sebagian tersebar pada pasaran lokal. Tujuan program ini yaitu meningkatkan produksi, pemasaran dan keuangan pada pengusaha kecil di Desa Pontoh Kecamatan Wori Kabupaten Minahasa Utara agar terampil dan mandiri secara ekonomi. Target khusus kegiatan ini menghasilkan produk ikan asap yang unggul dari segi rasa, dan daya awet serta memberikan kelangsungan usaha dan manajemen yang tangguh. Adapun metode pelaksanaan yang akan diterapkan pada program ini adalah 1) Permasalahan kelompok yang disepakati yaitu produksi, pemasaran dan keuangan; 2) Metode pendekatan yang akan ditawarkan untuk mengatasi persoalan kelompok yakni penyuluhan, pelatihan, pendampingan dan evaluasi; 3) Prosedur kerja untuk mendukung ke-3 aspek permasalahan, berturut-turut yaitu survei, penyuluhan, pelatihan, evaluasi, luaran, pelaporan.
\end{abstract}

Kata kunci: pengasapan, Desa Pontoh, produksi, pemasaran, keuangan.

\section{PENDAHULUAN}

Masyarakat Desa Pontoh berprofesi sebagai nelayan 60\%. Letak geografis di Desa Pontoh Kecamatan Wori Kabupaten Minahasa Utara Provinsi Sulawesi Utara dengan jumlah penduduk 1.678 jiwa (Data, 2018). Kelompok keluarga miskin $68 \mathrm{KK}$ dan keluarga penerima raskin $75 \mathrm{KK}$. Fasilitas pendidikan terdapat 1 TK dan 1 SD. Pengolah ikan asap terletak di pesisir pantai, dan memiliki potensi perikanan laut yang potensial untuk dikembangkan. Bahan baku yang digunakan didapat dari nelayan setempat, sehingga dari segi kualitas memiliki kelebihan yakni sebagian besar ikan sebagai bahan baku masih bermutu baik karena ikan baru tertangkap. 
Ikan asap merupakan ikan olahan tradisional Desa Pontoh. Produksi ikan asap Indonesia sebagian besar berasal dari Provinsi Sulawesi Utara. Namun masih diperhadapkan dengan beberapa permasalahan, antara lain kurang baiknya proses produksi khususnya penggunaan ruang pengasapan yang konstruksi terbuka, pemasaran yang masih terbatas dan modal usaha untuk keberlangsungan proses produksi yang minim. Sasaran program ini diarahkan pada industri pengolahan ikan asap. Sebagai mitra dari usulan ini yaitu kelompok pengusaha kecil pengolah ikan asap di Desa Pontoh yaitu Kelompok Pengasap Ikan Desa Pontoh.

Lokasi pengolahan ikan asap ini berada di pinggiran pantai Desa Pontoh. Hasil wawancara dengan ketua kelompok untuk banyaknya bahan baku ikan segar yang di olah setiap hari rata-rata $150 \mathrm{~kg} /$ hari. Peralatan dan perlengkapan yang digunakan masih tergolong tradisional. Sumber air yang digunakan untuk mencuci ikan berasal dari sumur, namun wadah yang digunakan untuk menampung air kurang baik dari segi kebersihan. Tempat pengeluaran isi perut relatif tidak terlalu baik dilihat dari prinsip sanitasi dan higienis karena hanya dikerjakan di atas meja kecil. Sebaiknya untuk tempat pengeluaran isi perut pada tempat yang lebih tepat misalnya pada meja kayu besar sehingga sanitasi dan higienisnya dapat terjaga karena tempatnya mudah dibersihkan dan aman dari bahan pencemar lainnya.

Ruang pengasapan tidak baik karena kurang efektif sirkulasi asap dan desain bangunan dibiarkan terbuka. Usaha pengasapan ikan asap di kelompok masih menggunakan sistem pengasapan panas dan suhu pengasapan tinggi dengan waktu pengasapan yang relatif singkat sehingga penetrasi komponen asap tidak merata, kadar air produk yang dihasilkan masih tinggi proses produksi yang belum saniter serta produk tidak dikemas.

Aspek Produksi Mitra sebagai berikut:

1. Untuk tempat penerimaan bahan baku ikan kurang bersih.

2. Penyimpanan bahan baku sebelum ikan diolah belum memenuhi prinsip sanitasi dan higienis.

3. Prinsip rantai dingin selama proses pengolahan kurang dilakukan.

4. Kelebihan dari industri kecil ini yaitu penggunaan bahan baku ikan yang tergolong mutu sangat baik karena ikan ditangkap langsung ditangani/langsung diasap.

5. Bentuk ikan asap yang diproduksi di industri ini masih menggunakan metode konvensional yang telah lama yakni ikan dicuci langsung diasap. Bentuk ikan asap ada yang dibelah dua ada yang tidak dibelah langsung diasap. ini telah lama diterapkan di industri pengolahan ini karena sudah sejak turun temurun dari orang tua mereka.

Tim pengusul memberikan kesempatan kepada para pengusaha ikan asap untuk mengemukakan permasalahan yang mereka alami selama ini. Hasil wawancara dan diskusi menghasilkan permasalahan yang teridentifikasi adalah:

1. Aspek produksi: desain ruang pengasapan terbuka mengurangi keefektifan alur asap ke produk ikan.

2. Aspek pemasaran/keuangan: produksi ikan asap dari desa ini dipasarkan di Desa Pontoh, Bulo, Darunu dan Manado yang didistrubusikan oleh pengolah ke pedagang pengecer.

Permasalahan lain yaitu kurangnya penerapan sanitasi dan higienis mulai dari penerimaan bahan baku, penyiangan, pengasapan, penyimpanan dan pengepakan. Sanitasi dan higienis merupakan keadaan yang mencerminkan kebersihan dan kesehatan, yang juga menjadi persyaratan untuk menghasilkan produk yang aman. Untuk menjaga sanitasi yang baik, maka pencucian merupakan sesuatu hal yang sangat penting untuk mencegah timbulnya kontaminasi pada produk perikanan yang dihasilkan.

Ruang pengasapan yang kurang baik dari segi sirkulasi asap karena kurang terjaganya produk ikan asap dari kotoran abu di sekitar ruang pengasapan, sehingga perlu perbaikan ruang pengasapan. Sangat perlu untuk membuat konstruksi tempat asap yang lebih efisien yaitu dengan menutup lokasi yang ada agar asap yang dihasilkan tidak menuju ke tempat lain selain di bagian ikan yang di asap. Konstruksi yang baik juga mencegah agar asap tidak mengganggu lokasi pemukiman penduduk karena daerah tersebut terletak pada area padat penduduk. Konstruksi lokasi pengasapan perlu dilengkapi dengan cerobong asap.

Wadah penampung ikan yang kurang baik sehingga dalam menentukan persoalan prioritas, telah disepakati kami sebagai pengusul program dengan mitra bahwa pengadaan wadah penampung ikan untuk kelompok ikan asap 4 buah. 
Dari hasil wawancara dan diskusi teridentifikasi bahwa mitra menggunakan jenis sabut kelapa sebagai bahan pengasap ini karena asap yang dihasilkan lebih banyak dan segi kualitas lebih baik dan banyak tersedia di Desa Pontoh.

\section{METODE KEGIATAN PKM}

Adapun metode pelaksanaan yang akan diterapkan pada program ini memberikan penyuluhan dan pelatihan. Tujuan metode ini adalah untuk menyadarkan pengusaha tentang perlunya memproduksi ikan asap yang higienis, berkualitas, dan tahan lama. Kegiatan yang akan dilaksanakan sebagai berikut:

\section{Penyuluhan}

Penyuluhan disampaikan kepada pengolah ikan asap di desa Pontoh meliputi:

- Pangan dan Kesehatan Konsumen.

- Kebersihan sarana pengolahan dan lingkungannya mempengaruhi mutu dan keamanan produk ikan asap.

- Disain ruang pengasapan ikan yang bersih, saniter, tidak mencemari lingkungan sekitar.

- Perbandingan ruang pengasapan ikan konstruksi terbuka dan tertutup (efektifitas penyerapan asap ke ikan).

- Aspek Pemasaran: penawaran, analisa peluang pasar.

\section{Pelatihan}

Sebelum pelatihan, dibangun konstruksi ruang pengasapan tertutup pada lokasi mitra wadah penampung air bersih dan wadah penampung ikan sesuai usulan alat penunjang. Setelah dilakukan penyuluhan terhadap pelaku industri pengolah ikan asap, kemudian ditindaklanjuti dengan pelatihan pengolahan ikan asap dengan perlakuan sebagai berikut:

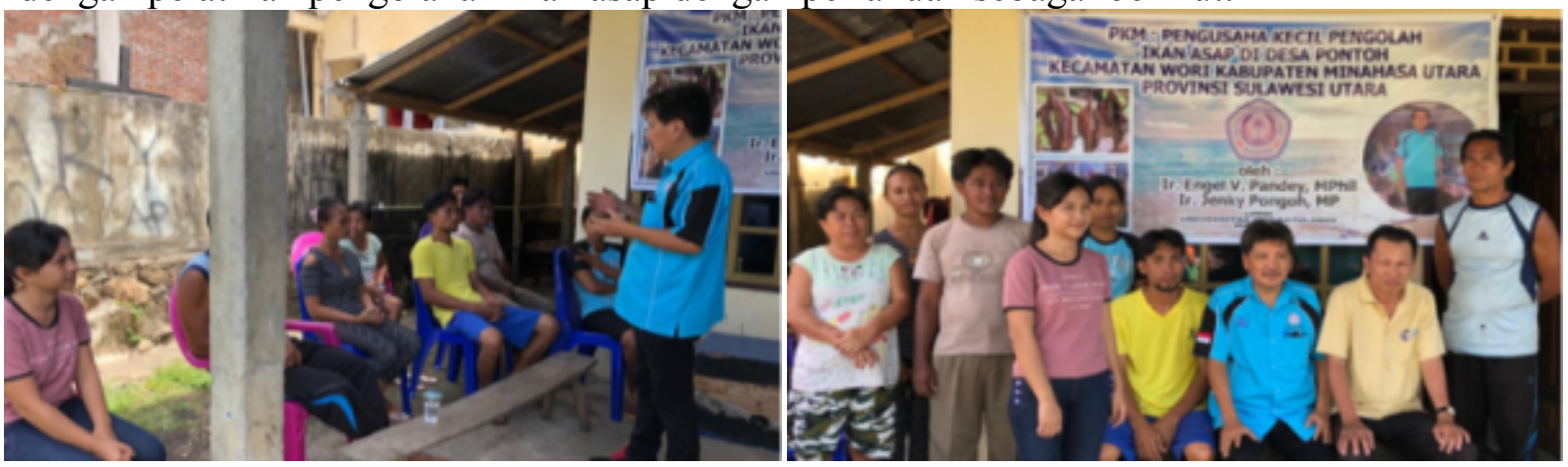

Mitra 1: Ikan diasap pada ruang pengasapan tertutup, menggunakan peralatan penunjang wadah penampung air bersih dan wadah penampung ikan menggunakan sabut kelapa sebagai bahan pengasap.

Mitra 2: Ikan diasap pada ruang pengasapan terbuka, menggunakan peralatan yang biasa mereka gunakan. menggunakan sabut kelapa sebagai bahan pengasap.

Tujuan dari pengabdian ini adalah membandingkan penggunaan ruang pengasapan tertutup dan terbuka. Setelah pelatihan produksi selesai dilanjutkan dengan perbaikan ruang pengasapan dan peralatan penunjang pada ke dua mitra.

\section{Pendampingan}

Pendampingan dilakukan kepada ke-2 mitra meliputi aspek produksi, pemasaran dan keuangan dengan jangka waktu per-minggu.

\section{Evaluasi}

Evaluasi akan dilakukan selama 2 bulan dengan membagikan cek list proses pengolahan ikan asap sesuai prinsip sanitasi dan higienis serta membandingkan kegiatan yang sebelum dan sesudah menerima penyuluhan dan pelatihan. 


\section{HASIL DAN PEMBAHASAN}

Kegiatan PKM yang dilaksanakan pada kelompok pengolah ikan asap di Desa Pontoh Kecamatan Wori Kabupaten Minahasa Utara telah mencapai sasaran dan berhasil guna bagi kedua mitra. Kedua kelompok pengolah mendapatkan manfaat yang maksimal selama kegiatan ini, penyuluhan dan pelatihan mengenai sortasi bahan baku ikan cakalang, pengolah ikan cakalang asap menggunakan metode yang tepat, penggunaan bahan pengemas yang saniter dan higienis serta pengelolaan keuangan yang baik dan pemasaran produk yang benar.

Kegiatan ini diawali dengan melaksanakan survei lapangan di tempat pengolahan ikan asap kedua mitra. Lokasi tempat pengasapan dan lingkungan sekitarnya belum cukup memadai sebagai tempat pengolahan ikan, rumah asap masih sangat sederhana dengan peralatan pengasapan seadanya. Kebersihan lingkungan sekitar tempat pengasapan perlu mendapat perhatian tentang sanitasi dan higienis bagi produk olahan makanan (ikan). Tempat penampungan bahan baku ikan segar yang terbatas dimana hal ini mempengaruhi kualitas bahan baku untuk ikan asap. Dari percakapan yang dilakukan selama kegiatan ini kedua kelompok pengolah menyampaikan semua keterbatasan dan kendala yang dihadapi, mereka juga menyampaikan niat yang besar untuk perubahan usaha mereka ke arah yang lebih baik dengan kemauan untuk menerima masukan dari berbagai pihak.

Tahapan pertama kegiatan ini yaitu melakukan penyuluhan dan pelatihan mengenai sortasi bahan baku ikan yang berkualitas baik. Hal ini penting karena untuk menghasilkan produk akhir yang baik, kelompok pengolah harus memperhatikan kualitas bahan baku yang digunakan. Cara penggunaan tempat penyimpanan bahan baku yaitu cool box juga dilakukan selama kegiatan ini sehingga ikan yang dibeli dengan kualitas yang baik dapat segera disimpan dalam penyimpanan dingin. Bantuan pengadaan cool box bagi kelompok pengolah sangat bermanfaat, juga diajarkan cara penggunaannya sehingga mereka dapat segera menggunakannya untuk menyimpan bahan baku ikan segar. Selama ini kendala yang mereka hadapi yaitu ketika bahan baku berlimpah dan belum dapat mengolah ikan saat itu juga mereka tidak mempunyai tempat penyimpanan dingin agar dapat menjaga kualitas bahan baku untuk diolah keesokan harinya.

Kegiatan selanjutnya yaitu pelatihan tentang tahapan proses produksi ikan cakalang asap yang menggunakan metode yang tepat yaitu dengan memperhatikan suhu dan waktu pengasapan. Juga bahan bakar yang digunakan, sehingga kualitas ikan asap akan lebih baik.

Tabel 1. Hasil analisis Proksimat cakalang asap menggunakan bahan bakar sabut kelapa.

\begin{tabular}{lcrrr}
\hline Perlakuan Pengasapan & Kadar Air & Kadar Protein & Kadar Lemak & Kadar Abu \\
\hline Cakalang Asap & $58,25 \pm 0,04$ & $38,10 \pm 1,02$ & $1,42 \pm 0,05$ & $2,12 \pm 0,03$ \\
\hline
\end{tabular}

Kebersihan selama pengolahan harus diperhatikan yaitu sejak pencucian ikan menggunakan air bersih sehingga akan menghasilkan ikan asap yang berkualitas dan aman untuk dikonsumsi. Dianjurkan untuk tidak menggunakan bahan pewarna tambahan, apalagi bahan pewarna yang digunakan tersebut berbahaya untuk digunakan sebagai pewarna bahan pangan. Setelah mengikuti pembinaan dan pendampingan dalam hal penyuluhan mengenai pengasapan serta prinsip-prinsip sanitasi dan higienis pengolah ikan cakalang asap mampu menerapkan dan mempraktekan caracara pengolahan, dan penyimpanan produk yang dijual agar mutu dan kualitas produk terjamin yang berdampak pada peningkatan produksi dan pemasaran.

\section{KESIMPULAN}

Kegiatan pelaksanaan PKM di Desa Pontoh Kecamatan Wori Kabupaten Minahasa Utara dapat disimpulkan bahwa:

1. Penerapan sistem sanitasi dan higienis di tempat penjualan ikan masih perlu ditingkatkan melalui pelatihan dan penyuluhan yang lebih intensif.

2. Pada kegiatan penyuluhan dan pelatihan sortasi ikan cakalang, pengesan ikan di dalam cool box, metode pengasapan ikan yang tepat, pengemas yang saniter/higienis serta pelatihan sanitasi lingkungan telah terjadi peningkatan pemahaman yang signifikan. 


\section{DAFTAR PUSTAKA}

Afrianto, E dan E. Liviawaty, 1989. Pengawetan Dan Pengolahan Ikan. Kanisius. Yogyakarta.

Fawzya, YN. Murniyati dan Suryaningrum TD. 2011. Persyaratan Pengolahan Produk Perikanan. Balai Besar Penelitian dan Pengembangan Pengolahan Produk dan Bioteknologi Kelautan dan Perikanan. Kementerian Kelautan dan Perikanan.

Gue, H. 2003. Warna Alami Pada Ikan Asap Yang Dibuat Dari Bahan Baku Dengan Tingkat Kesegaran Dan Lama Pengasapan Yang Berbeda Serta Kesukaan Terhadap Ikan Asap Yang Diberi Zat Pewarna. Skripsi. Fakultas Perikanan Dan Ilmu Kelautan. Unsrat. Manado.

Salindeho N. Purnomo, H. , Yunianta, and Kekenusa J. 2014. Physicochemical Characteristics and Fatty Acid Profile of Smoked Skipjack Tuna (Katsuwonus pelamis) Using Coconut Fiber, Nutmeg Shell and Their Combination as Smoke Sources. International Journal of Chem Tech Research. CODEN (USA): IJCRGG 6 (7): 3841-3846. ISSN-09744290

Salindeho N and Hens Onibala. 2017. Physico-Chem ical Characteristics, Fatty Acid Profile and Polycyclic Aromatic Hydrocarbon of Skipjack Tuna (Katsuwonus pelamis) Smoked in Smoking Material of Nutmeg Shells for Different Duration in Bitung Municipality, North Sulawesi Province. International. International Journal of Chem Tech Research. CODEN(USA) ISSN:0974-4290 IJCRGG. Vol.10, No.4, pp 506-512- 2017.

Wibowo, S. 2000. Industri Pengasapan Ikan. Penerbit PT. Penebar Swadaya. Jakarta.

Winarno, F.G. 1980. Kimia Pangan. Pus BangTepa Food Technology Development Center. Institut Pertanian Bogor. 